\title{
Fair Value and Volatility in the Cases of Assets Securitization, Derivative Hedging and Loan Loss Provisioning
}

\author{
Lan Sun \\ UNE Business School, University of New England Australia, Armidale, Australia \\ Email: lansun@une.edu.au
}

Received 14 September 2015; accepted 23 October 2015; published 27 October 2015

Copyright (C) 2015 by author and Scientific Research Publishing Inc.

This work is licensed under the Creative Commons Attribution International License (CC BY).

http://creativecommons.org/licenses/by/4.0/

(c) (i) Open Access

\section{Abstract}

The concept of fair value is a key element in the international accounting standards and its implementation poses serious concerns in terms of financial stability. There are a number of issues which are particularly important for financial stability that are evidenced in the GFC and have been received much attention in the reform of fair value regime, namely assets securitization, derivatives hedging and loan loss provisioning. This study analyzes and shows the way in which financial reporting for fair values could create volatility through the processes of assets securitization, derivative hedging and loan loss provisioning. The other objectives of financial reporting, namely reliability and comparability, are achievable only if the measures of fair value are reliable and relevant. Fair value measurement is supported on the ground that it provides information which is more relevant to the economic substance and presumably such information will be more useful to investors. Nonetheless, changes in the market landscape and financial innovation are evident and accounting standards so far have not kept pace with the development of financial market which is revealed in this study by analyzing the transactions of assets securitization, derivative hedging and loan loss provisioning.

\section{Keywords}

Fair Value, Volatility, Assets Securitization, Derivative Hedging, Loan Loss Provisioning

\section{Introduction}

Accounting information plays a vital role in stabilizing financial markets. Accounting standards which mirror the economic substance should be also applied in a consistent manner across entities. A current debate on ac- 
counting information and standards concerns whether historical cost accounting should be replaced by fair value accounting. When there is an active market, financial instruments can be measured properly under fair value accounting as we can observe the prices. However, bank loans which are not actively traded, historical cost accounting may be more reliable in measuring these instruments. Many researchers believe that the use of fair value accounting can better reflect underlying economic values and there is a trend for international accounting standards to use fair value more pervasively. Others concerning the use of fair value accounting will have an impact on financial stability that might derive from the increased volatility in reported earnings. Under historical cost accounting, changes in value are normally not recognized until realized. In contrast, under fair value accounting, changes in value, for example, unrealized gains and losses from asset revaluation, are recognized in current reported earnings. A fair value accounting system is more volatile because fair values involve estimation of future cash flows; any changes in estimates will result in changes in the fair value. The financial statement accounts that will be affected include individual asset and liability accounts as well as summary accounts such as net income. The IASB's Framework [1] defines assets and liabilities from first principle and leaves income and expenses as a residual. So income is defined as changes in assets and liabilities and it is important to recognize that net income as a summary account will aggregate the volatility in assets and liabilities. Fair value accounting is forward-looking in nature and requires the revaluation of assets and liabilities whenever there is a change in their market prices. Therefore, financial accounts under a fair value accounting system will change more from period-to-period as compared to that of historical cost accounting, leading to increased volatility in earnings. Fair value measurement will not only affect the balance sheet but also the income statement. Essentially, fair value measures assets and liabilities on the balance sheet and any changes in fair value are recognized as gains and losses in the income statement. IFRS in many ways encourages the use of fair value in measuring assets and liabilities. The changes in fair values of assets and liabilities are then passed on to the income statement as profits and losses. If a fixed-asset is valued at fair value and it is increased in fair value, the increased amount needs to be recognized in the balance sheet and also the gain is recognized as earnings in the income statement. Therefore, we can state that earnings by large are determined through a balance sheet fair value accounting. The best measure of fair value is quoted prices observable from an active market. When active markets do not exist for many assets and liabilities, fair value estimation requires judgments and these judgments can lead to variations in fair value balance sheet accounts, which in turn will be passed onto the income statement accounts likewise earnings.

One accounting standard IAS39 was particularly exposed to financial stability discussion during the GFC. This standard was first published in 1998 which sought to improve the alignment of the measurement of financial instruments with the economic substance. During the GFC, this standard was criticized to be complex and the "mixed attribute" model of accounting, where some items such as bank loans were recorded at historical cost while others trading financial assets were measured at fair value, was argued to contribute to an instable financial system. Under the "mixed attribute" model, financial assets are classified into four categories: 1) financial assets (investment) held for trading are measured at fair value, with fair value changes are recognized in the income statement; market securities such as government bills and bonds, asset-backed securities, bonds, equities and derivatives can be classified as trading assets; 2) held-to-maturity (HTM) investments are measured at historical cost adjusted for amortization and are subject to impairment testing; 3 ) available-for-sale financial assets (AFS) are measured at fair value, changes in fair value are unrealized gains and losses and recognized in the shareholders' equity account as "accumulate other comprehensive income”; 4) originated loans are held at historical cost and adjusted for amortization and are subject to impairment testing.

The use of fair value for trading assets, AFS and other items became increasingly unpopular in 2008 and 2009 when market prices fell sharply. The fall in property prices perceived credit risk might increase, leading a decline in the fair value of banks' assets, which would in turn reduce bank capital and reduce lending activities, so further slow down the economy. When the property market is doing well, we would expect a reverse mechanism. This reflects the procyclical effect of fair value accounting, increasing bank profits and capital that would support the overextension of credit in bull markets and decreasing profits and capital in bears markets that would further restrain their lending. Accounting was blamed by some researchers as the root cause of the financial crisis that many banks were not able to recover the full amount of the home mortgages when the property market fell and all the losses from declining fair value had to be written off against capital. According to BASEL II the international standard for computing capital adequacy in banks, a key requirement is that a bank must maintain a minimum regulatory capital equal to at least $8 \%$ of the risk-weighted market value of its assets [2]. So the reduc- 
tion in the bank capital base meant that lenders were not able to maintain previous lending levels. Many banks, especially a number of French financial institutions who had large holdings of "trading" securities desperately wanted to avoid huge losses on their holdings and urged the European Commission to pressure the IASB to amend the rule to allow for reclassification of "trading" assets as "held to maturity". Under the pressure, the IASB temporarily suspended the normal due process and amended IAS 39 in 2008.

As IAS 39 is considered to be overly complex and difficult to apply, the IASB issued IFRS 9 which introduced a new classification and measurement for financial assets with effective date of January 2013 but available for early adoption. The IFRS 9 is built on a mixed attribute measurement approach with the fair value and amortized cost. For example, under IAS 39, debt instruments may be classified into the four categories: fair value, loan and receivables, held to maturity and available for sale. However, IFRS 9 will classify debt instruments either at amortized cost of fair value based on a Business Model. The objective of entity's business model is either to collect all contractual cash flows of the instruments; or to sell instruments prior to maturity and realize fair value changes. So, if an asset is held within a Business Model whose objective is to hold the asset to collect contractual cash flows it should be classified at amortized cost. While if an asset is held within a Business Model whose objective is to sell instruments prior to maturity and realize fair value changes then the assets should be classified at fair value. The important feature of the Business Model test is a matter of fact and not management intention. Under IFRS 9, all financial assets and liabilities are subject to impairment. A financial asset is impaired if the decline in value is significant or prolonged. Further, investment assets written down may subsequently be written up and the reverses of impairments appear on the income statement. The EU failed to endorse IFRS 9 because of the adverse effect of fair value on earnings. Under IAS 39, the banks of countries like Greece, Italy, Spain and Portugal had invested in those countries' government bonds which were classified as available for sale assets and measured at amortised cost. However, these debt instruments should be measured at fair value if the banks' business is to sell the bonds under IFRS 9. When these European countries' debt has been downgraded, the banks incurred huge losses from recognizing impairment losses. The impairment losses rose when fair value was substantially below cost and such losses had a very negative impact on the banks' financial statements, lowering both assets and earnings. On 13 May 2011 the IASB issued IFRS 13 Fair Value Measurement. IFRS 13 defines fair value and sets out a single framework for measuring fair value and requires disclosures about fair value measurements. IFRS 13 applies when other IFRSs require or permit fair value measurements. It does not introduce any new requirements to measure an asset or a liability at fair value, change what is measured at fair value in IFRSs or address how to present changes in fair value. The new requirements are effective for annual periods beginning on or after 1 January 2013, with earlier application permitted.

The remainder of the paper is organized as follows. Section 2 derives whether fair value contributes to volatility; Section 3 analyzes the securitization process through which fair value affects earnings volatility; Section 4 analyzes derivative hedging and how fair value creates volatility in hedging accounting; Section 5 discusses whether measuring loans at fair value tends to amplify procyclicality effect during the GFC; Section 6 concludes the paper.

\section{Fair Value and Volatility}

Earnings volatility can be attributed to the market. It also can be a consequence of errors in estimating fair values. Assume we estimate the fair value of a financial asset home mortgage. When the mortgage is traded in the market, we can estimate the fair value of the mortgage as the market price plus an error, that is, $X=X^{\prime}+\varepsilon$ where $X$ is the fair value of the security, $X^{\prime}$ is the market price that can be observed in the market, and $\varepsilon$ is the estimation error. Recall that the volatility, or variance is $\sigma_{X}^{2}=\sigma_{X^{\prime}}^{2}+\sigma_{\varepsilon}^{2}+2 \operatorname{cov}\left(X^{\prime}, \varepsilon\right)$, if the model is well specified that $X^{\prime}$ is uncorrelated with the error term, the variance of the $X$ is the sum of the variances of $X^{\prime}$ and $\varepsilon$. So, fair values carry two components of volatility, the volatility from the fluctuation of underlying market prices and from the estimation errors, subsequently those volatilities will be passed on to earnings. Recall the three levels' hierarchy, when Level 1 and 2 inputs quoted market prices are used, estimation error is small and fair value volatilities are mainly driven by the markets. When a market is volatile, one would expect a higher volatility in reported earnings since it is more likely that next period's price will differ from this period's price and such price difference creates volatility in the fair value that would recognized in aggregate earnings.

Nonetheless, this earnings volatility is not caused by the fair value accounting system; rather it is a reflection of economic reality that should be recognized in the financial statements. When financial assets or liabilities are 
not actively traded on liquid markets and market prices are not available, fair values must be estimated as the present value of expected future cash flows associated with the asset or liability, discounted by an appropriate discount rate. This is the Level 3 inputs require management estimation and discretion. In this case, the future cash flows are unknown, the timing of future cash flows is uncertain and the discount rate is fluctuated, the estimation error and its volatility could assign more weight in determining the variance of fair values and earnings. Therefore, an excessive reliance on fair values, especially when financial markets are illiquid, runs the risk that the volatility reflected in earnings is artificial, driven by estimation errors.

Apart from the market volatility and the estimation error volatility, the mixed-measurement approach in accounting can also lead to earnings volatility. The "mixed attribute" model proposed by the IAS 39 illustrates a classical case for us. That is, some financial assets are classified as trading assets and measured at fair value, with valuation changes taken through the profit and loss account; some assets that classified as held-to-maturity investment are measured at amortised cost; some available-for-sale financial assets are measured at fair value, with valuation changes taken directly to equity; and originated loans are measured at amortised cost. The kind of mixed-measurement results in a balance sheet mismatch because some assets recorded at fair value are financed by liabilities that recorded at cost and any changes in interest rates will be reflected in the financial statements unduly, leading to great earnings volatility. For example, when there is an increase in market interest rates, the values of financial trading assets decrease and this decrease is recognized as losses in the income statement; whereas the values of originated loans also decrease but this decrease is not recognized. This mixed fair value and historical cost measurement will result in lower net assets and lower earnings when the interest rate is increased. Conversely, a decrease in market interest rates will lead to a higher net assets and higher earnings. In this perspective, the fair value mixed-measurement and mismatched balance sheet position creates incentives to encourage banks to hedge securities to maximize short-term profits at the expenses of long-term investment deeds. In 2010, IASB issued IFRS 9 to measure financial liabilities at fair value. If change in fair value is due to the market, a change in market interest rate would be one example; the change in fair value is reported in the profit and loss accounts. If a bank runs into a risk of being default and its debt rating has been downgraded, the change in fair value should be reported in other comprehensive income.

The IASB's actions in response to the GFC are more likely to improve the global financial stability on one hand. The medium term action is to address accounting convergence- aiming for consistent, comparable, unbiased, transparent, and relevant information about the economic performance and condition of business. Financial reporting must remain relevant and informative to investors, and should not impose unnecessary or costly burdens that do not add to investor understanding. The increased comparability of financial reporting is more likely to restore investors' confidence to make resource allocation decision effectively and therefore to enhance global financial stability. Financial stability requires accounting standards to be consistent; principles-based; reliable and relevant; comparable and understandable, able to recognize risks and incorporate sound risk management. On the other hand, financial reporting attributes, including comparability, are not solely a function of accounting standards. Other factors, such as government involvement, the type of legal system, capital market characteristics, the litigation environment, and the development of the accounting profession affect how standards are applied and enforced, and ultimately the quality of financial reporting. Given the number of factors that influence the comparability of international financial reporting, it is sometimes difficult to gauge whether the IASB's responses to the GFC will improve the issue.

\section{Fair Value and Assets Securitization}

A central debate during the GFC is the assets securitization because it is the major vehicle through which subprime mortgage is spread overall the world. In the early 1990s, the assets securitization was a financial innovation by the Wall Street and it was a large source of bank financing and the market grew to $\$ 9.3$ trillion in value by the end of 2007 [3]. Typical securitizations involve the repackaging of banks' financial assets, including home mortgages, corporate and personal loans into a pool of financial assets and selling rights to obtain cash flows from the pool of financial assets to new customers via securities issuance. Special purpose vehicles (SPVs) are normally involved in the process of securitization. SPVs are typically trusts and set up and managed by banks that often retain a subordinated interest in the SPV's assets. During the GFC, home mortgages and its securitizations were heavily exposed to the risk. In a typical home mortgage securitization, a mortgage lender such as a commercial bank originates housing mortgages and sells them to a special purpose vehicle (SPV). The SPV 
then repackages a large group of housing mortgages into wholesale securities (usually bonds), issues the securities to worldwide institutional investors, and use the proceeds raised from the securities issuance to pay the bank for the rights to obtain the cash flows from repayment of housing mortgages. The SPV will also appoint a service manager to collect the repayments due on the mortgage. This is a home mortgage securitization process that issues a number of asset-backed securities including collateralized debt obligations (CDOs) and collateralized mortgage obligations (CMOs), which are all marketable and supported by the value of underlying residential properties. The asset-back securities are composed of a range of senior to junior tranches based on credit ratings. The top tranche A is an asset class has a high credit rating, a lower default risk and a lower rate of return (usually has an AAA credit rating and it provides a risk-free rate of return to investors). Investors in tranche A will have a priority access to repayments than those in junior tranche B and in some case there could be more junior tranches (See Figure 1 for a home mortgage securitization process).

The securitization process provides several advantages to lenders/banks, allowing banks to diversify their asset holdings, extend capital base to wholesale money market, increase regulatory capital by transferring undesirable assets and liabilities off-balance sheet. Banks no longer have to hold capital against risk assets provided that there is no retain interest for the assets. The securitization also benefits investors, who are investment banks, hedged funds, pension funds, superannuation funds and insurance companies, by widening their choice of available investments including mortgages and other forms of debt. The bonds can be easily resold to the market and therefore offer investors a high liquidity. Investors may also find easier to analyze a pool of assets rather than an entire business. Finally, asset-backed securities are often regarded as low risk investment because those securities are "backed up" by assets such as properties.

So, what went wrong during the GFC? First, assets securitizations encourage banks to engage in excess lending. BASEL II requires that a bank must hold a regulatory amount of capital to against their assets to remain capital adequacy. By transferring financial assets to SPVs, banks were able to reduce assets from the balance sheet and therefore reduce the capital. Banks exploited this regulatory arbitrage and engaged in more risky lending. Second, when the property prices bubble burst in early 2007 and the sub-prime mortgage defaults increased, the value of asset-backed securities started to fall and this imposed losses on the ultimate investors. This was devastating for investment banks, hedge funds and institutional investors who have a high leverage. For a high leveraged investment bank, a sharp fall in the security values could wipe out the equity overnight, particularly, if the bank heavily invested in the lower tranche of the bonds. As a result, many investment banks collapsed including Lehman Brothers in the USA. Third, credit rating agencies failed to recognize the emergence of subprime lending had reduced the quality of mortgages. Rating agencies provided ratings based on historical default rates for mortgages of a similar type without anticipating negative changes in property prices and therefore underestimated the risk.

How did fair value affect assets securitizations? Through an assets securitization process, banks were able to create SPVs and transferred their assets (home mortgages) off the balance sheet. Investors had limited information about the quality of the mortgages that banks originated and securitized. They also had difficulties in assessing the risk and fair value of the securitized mortgages after the securitization. Hull [4] suggests the practice of CDOs squared and cubed. For example, there were CDOs of CDOs, which is CDOs squared, where the first SPV issued CDOs to the second SPV, who subsequently repackaged it and sold to the third SPV. The CDOs that the third SPV held were actually created through twice securitizations. In a similar vein, CDOs cubed were

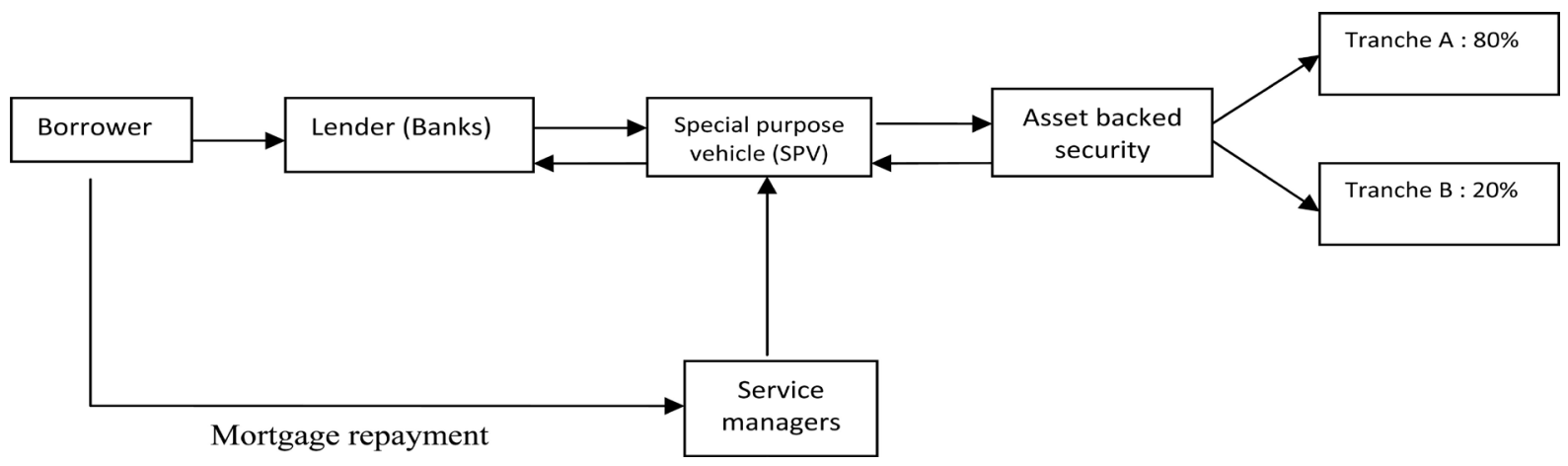

Figure 1. Home mortgage securitization process. 
CDOs of CDOs squared. The further the SPV's assets were removed from the initial securitization transaction, the harder to measure the risk and fair value. Ryan [5] suggests that financial activities of SPVs are not regulated that they are essentially a shadow banking system. As a result of the complexity, it became very difficult for investors to determine the fair value and riskiness of their investment. The U.S. accounting standard SFAS 140 provides that a bank transfers assets to a SPV via assets securitization that qualify as sales to derecognize the asset from the bank's financial statement. An asset transfer can be treated as a sale when the following conditions have been met: the transferred assets have been legally isolated from the transferor; the transferee has the ability to pledge or exchange the assets; and the transferor does not maintain effective control over the assets. If the transaction satisfies sale accounting treatment, the bank is required to derecognize the assets with receivables are removed from the balance sheet and the cash is recorded. If the transaction fails to meet the conditions, then the bank should record the transferred asset as a collateralized borrowing and the SPV's financial statements are required to be consolidated with those of the bank. But most banks would avoid consolidation of the SPV by structuring the securitization to meet the sale accounting requirement. International accounting standards for assets securitization during the GFC was specified in IAS 39. Broadly, accounting treatments for a transferred asset to be qualified as a sale are similar to those in the U.S. standard. The major difference is that the U.S. standard bases control on legal isolation, whereas IAS 39 uses a risks and rewards approach to financial asset derecognition. IAS 39 (paragraphs 20) specifies that asset derecognition is based on the transfer of "substantially all the risk and rewards of ownership" and as a result international accounting standard generally leads to more frequently consolidation [6].

A common feature of securitizations is that banks retain an interest in the transferred assets by holding the most junior asset-backed securities issued by SPVs. Retained interest helps banks to either monitor the assets transferred to SPVs or protect SPVs from future potential losses in value of transferred assets as banks will absorb first loss through holding the most junior class assets. IAS 39 requires banks to use fair values to allocate the carrying value of the transferred assets between the assets sold and the retained interests. A gain or loss is recorded for the assets sold, and interest retained by the bank is measured at fair value. For example, Figure 2, Bank X organizes a mortgage contract where borrower $\mathrm{Y}$ will receive $\$ 37.91 \mathrm{k}$ and make five equal repayments of $\$ 10 \mathrm{k}$ in the next five years. The mortgage lending rate is $10 \%$. To facilitate the lending, Bank $\mathrm{X}$ borrows $\$ 31.94 \mathrm{k}$ at $8 \%$ and needs to pay back the creditor in five equal installments of $\$ 8 \mathrm{k}$ in the next five year. The

Assumptions:

Mortgage contract: the bank lends mortgage to a homeowners at a lending rate of $10 \%$.

Homeowners will receive $\$ 37.91 \mathrm{k}$ and make repayments in 5 equal installments of $\$ 10 \mathrm{k}$.

$\begin{array}{cccccc}\$ 37.91 & 10 & 10 & 10 & 10 & 10 \\ 0 & 1 & 2 & 3 & 4 & 5 \text { (year) }\end{array}$

PV of mortgage@10\%=\$37.91k

Borrowing contract: the bank borrow from creditors at a borrowing rate of $8 \%$. The bank will pay $\$ 31.94 \mathrm{k}$ and make repayments in 5 equal installments of $\$ 8 \mathrm{k}$.

$\begin{array}{llllll}\$ 31.94 & 8 & 8 & 8 & 8 & 8 \\ 0 & 1 & 2 & 3 & 4 & 5 \text { (year) }\end{array}$

PV of loan@8\%=\$31.94k

The bank initially raises $\$ 5.97 \mathrm{k}$ in cash from the spread of interest rates $(10 \%$ lending rate vs. $8 \%$ borrowing rate). The bank should enter the deals as long as the internal rate of return (IRR) to shareholders is below $20.09 \%$.

$\begin{array}{llllll}\$ 5.97 & 2 & 2 & 2 & 2 & 2 \\ 0 & 1 & 2 & 3 & 4 & 5 \text { (year) }\end{array}$

PV of cash flow@20.09\%=\$5.97

PV of cash flow@10\%=\$7.58

Figure 2. Examples of assets securitization. 
bank initially raises $\$ 5.97 \mathrm{k}$ in cash from the spread of lending and borrowing interest rates. Assume the cash can be reinvested in an internal rate of return (IRR) $20.09 \%$ and as long as IRR to shareholders is below $20.09 \%$, the bank should enter the deals. Without a securitization, the balance sheet and income statement are shown in the Figure 3. However, if Bank X securitizes the home mortgage and transfers the mortgage to a SPV Z, who then sells classes of securities representing parts of the cash flow to outside investors, we can see a different balance sheet and income statement in Figure 4. Assume $80 \%$ of the cash flows to outside investors are Tranche A (the senior tranche) and the remaining $20 \%$ in Tranche B (the junior tranche) is retained by the bank. Assume Tranche A investors are willing to pay $\$ 31.94 \mathrm{k}$ to earning an 8\% return (assume the risk free rate is 5\%). The fair value of the mortgage transferred should be equal to the mortgage's carry value on the bank's balance sheet "unless a fundamental attribute of the underlying asset has changed" [7]. So, the fair value of the mortgage is $\$ 37.91 \mathrm{k}$ and the fair value of retained interest in Tranche B is the difference between the fair value of the mortgage and the part sold to Tranche A, i.e., $\$ 37.91 \mathrm{k}-\$ 31.94 \mathrm{k}=\$ 5.97 \mathrm{k}$. Bank X uses the cash from Tranche A to pay off its borrowing $\$ 31.94 \mathrm{k}$ and derecognizes the mortgage from its balance sheet. The fair value estimation could yield a different result if we arbitrarily choose an IRR of $10 \%$ rather than $20.09 \%$. Figure 5, using a $10 \%$ discount rate, retained interest is valued at $\$ 7.58 \mathrm{k}$, plus the PV of Tranche A $\$ 31.94 \mathrm{k}$, gives a total value (cash received and retained interest) of $\$ 39.52 \mathrm{k}$ and the retained interest account for 19 percent of the total value of mortgage. The book value of the retained interest is $\$ 7.20 \mathrm{k}$ (19 percent of the original mortgage value $\$ 37.91 \mathrm{k}$ ). The bank transfers $\$ 37.91 \mathrm{k}$ mortgage and receives $\$ 31.94 \mathrm{k}$ cash and retained interest has a book value of $\$ 7.20$ $\mathrm{k}$, resulting in a gain of $\$ 1.23 \mathrm{k}$. The fair value of retained interest is $\$ 7.58 \mathrm{k}$ and the book value is $\$ 7.20 \mathrm{k}$, representing an additional again $\$ 0.38 \mathrm{k}$. If the retained interest security is classified as trading asset, the $\$ 0.38 \mathrm{k}$ could be recognized as income. The bank has discretion over the discount rate. Figure 4, there is no gain on securitization when the IRR is $20.09 \%$ whereas Figure 5, gains on securitization and changes in fair value of retained interest are artificially created through changing the discount rate to $10 \%$. The bank also has discretion over the timing of income recognition. Figure 4 the bank must wait until cash is received to record the gain as interest income whereas Figure 5 the bank immediately records the gain on securitization and changes in fair value of retained interest as earnings. As the size of securitization continues to grow, more gains will be recognized and hence the reported earnings will increase.

Niu and Richardson [8] point out those gains from assets securitizations are less reliable than other earnings components in asset valuations. Moreover, off-balance sheet debt is as risky as those on-balance sheet, they have the same risk-relevance in explaining the beta of capital asset pricing model. Indeed, a high quality financial information is the key to firm valuation and the pricing of issued securities and average investors rely on such information to make judgments regarding the performance and wealth creation of reporting entities. Despite a

Balance sheet as of the end of year

\begin{tabular}{|c|c|c|c|c|c|c|}
\hline & 0 & 1 & 2 & 3 & 4 & 5 \\
\hline Mortgage & 37.91 & 31.70 & 24.87 & 17.36 & 9.09 & 0 \\
\hline Cash & $\underline{0}$ & $\underline{2.00}$ & $\underline{4.00}$ & $\underline{6.00}$ & $\underline{8.00}$ & $\underline{10.00}$ \\
\hline Total Assets & $\underline{\underline{37.91}}$ & $\underline{\underline{33.70}}$ & $\underline{\underline{28.87}}$ & $\underline{\underline{23.36}}$ & $\underline{17.09}$ & $\underline{\underline{10.00}}$ \\
\hline Loan & 31.94 & 26.50 & 20.62 & 14.27 & 7.40 & 0 \\
\hline Equity & 5.97 & 5.97 & 5.97 & 5.97 & 5.97 & 5.97 \\
\hline Retained Earnings & $\underline{0}$ & $\underline{1.23}$ & $\underline{2.28}$ & $\underline{3.12}$ & $\underline{3.72}$ & $\underline{4.03}$ \\
\hline Total Liabilities \& Equity & $\underline{\underline{37.91}}$ & $\underline{\underline{33.70}}$ & $\underline{\underline{28.87}}$ & $\underline{\underline{23.36}}$ & $\underline{\underline{17.09}}$ & $\underline{\underline{10.00}}$ \\
\hline \multicolumn{7}{|c|}{ Income statement as of the end of year: } \\
\hline & 0 & 1 & 2 & 3 & 4 & 5 \\
\hline Interest Income $(10 \%)$ & & 3.79 & 3.17 & 2.49 & 1.74 & 0.90 \\
\hline Interest Expense (8\%) & & $\underline{2.56}$ & $\underline{2.12}$ & $\underline{1.65}$ & $\underline{1.14}$ & $\underline{0.59}$ \\
\hline Net Income & & $\underline{1.23}$ & $\underline{1.05}$ & $\underline{\underline{0.84}}$ & $\underline{\underline{0.60}}$ & $\underline{\underline{0.31}}$ \\
\hline
\end{tabular}

Figure 3. Without securitization. 
Balance sheet as of the end of year:

\begin{tabular}{|c|c|c|c|c|c|c|}
\hline & 0 & 1 & 2 & 3 & 4 & 5 \\
\hline Mortgage & 0 & 0 & 0 & 0 & 0 & 0 \\
\hline Retained Interest & 5.97 & 5.17 & 4.21 & 3.06 & 1.68 & 0 \\
\hline Cash & $\underline{0}$ & $\underline{2}$ & $\underline{4}$ & $\underline{6}$ & $\underline{8}$ & $\underline{10}$ \\
\hline Total Assets & $\underline{5.97}$ & $\underline{\underline{7.17}}$ & $\underline{\underline{8.21}}$ & $\underline{\underline{9.06}}$ & $\underline{\underline{9.69}}$ & $\underline{10}$ \\
\hline Loan & 0 & 0 & 0 & 0 & 0 & 0 \\
\hline Equity & 5.97 & 5.97 & 5.97 & 5.97 & 5.97 & 5.97 \\
\hline Retained Earnings & $\underline{0}$ & $\underline{1.20}$ & $\underline{2.24}$ & $\underline{3.09}$ & $\underline{3.72}$ & $\underline{4.03}$ \\
\hline Total Liabilities \& Equity & $\underline{5.97}$ & $\underline{7.17}$ & $\underline{8.21}$ & $\underline{9.06}$ & $\underline{9.69}$ & $\underline{10}$ \\
\hline \multicolumn{7}{|c|}{ Income statement as of the end of year: } \\
\hline & 0 & 1 & 2 & 3 & 4 & 5 \\
\hline Interest Income $(20.09 \%)$ & & 1.20 & 1.04 & 0.85 & 0.63 & 0.31 \\
\hline Interest Expense & & $\underline{0}$ & $\underline{0}$ & $\underline{0}$ & $\underline{0}$ & $\underline{0}$ \\
\hline Net Interest Income & & $\underline{1.20}$ & $\underline{1.04}$ & $\underline{\underline{0.85}}$ & $\underline{\underline{0.63}}$ & $\underline{\underline{0.31}}$ \\
\hline Gain on Securitization & 0 & & & & & \\
\hline
\end{tabular}

Note: The bank must wait until cash is received to record the gain as interest income.

Figure 4. With securitization when IRR is $20.09 \%$.

Balance sheet as of the end of year:

\begin{tabular}{|c|c|c|c|c|c|c|}
\hline & 0 & 1 & 2 & 3 & 4 & 5 \\
\hline Mortgage & 0 & 0 & 0 & 0 & 0 & 0 \\
\hline Retained Interest & 7.58 & 6.33 & 4.96 & 3.45 & 1.79 & 0 \\
\hline Cash & $\underline{0}$ & $\underline{2}$ & $\underline{4}$ & $\underline{6}$ & $\underline{8}$ & $\underline{10}$ \\
\hline Total Assets & $\underline{\underline{7.58}}$ & $\underline{8.33}$ & $\underline{\underline{8.96}}$ & $\underline{\underline{9.45}}$ & $\underline{\underline{9.79}}$ & $\underline{10}$ \\
\hline Loan & 0 & 0 & 0 & 0 & 0 & 0 \\
\hline Equity & 7.58 & 7.58 & 7.58 & 7.58 & 7.58 & 7.58 \\
\hline Retained Earnings & $\underline{0}$ & $\underline{0.75}$ & $\underline{1.38}$ & $\underline{1.87}$ & $\underline{2.21}$ & $\underline{2.42}$ \\
\hline Total Liabilities \& Equity & $\underline{\underline{7.58}}$ & $\underline{\underline{8.33}}$ & $\underline{\underline{8.96}}$ & $\underline{\underline{9.45}}$ & $\underline{\underline{9.79}}$ & $\underline{\underline{10}}$ \\
\hline \multicolumn{7}{|c|}{ Income statement as of the end of year: } \\
\hline & 0 & 1 & 2 & 3 & 4 & 5 \\
\hline Interest Income $(10 \%)$ & & 0.75 & 0.63 & 0.49 & 0.34 & 0.18 \\
\hline Interest Expense & & 0 & 0 & 0 & 0 & 0 \\
\hline Net Interest Income & & $\underline{0.75}$ & $\underline{0.63}$ & $\underline{0.49}$ & $\underline{0.34}$ & $\underline{0.18}$ \\
\hline Gain on Securitization & 1.23 & & & & & \\
\hline Fair Value Retained interest & 0.38 & & & & & \\
\hline Net Income & $\underline{\underline{1.61}}$ & $\underline{\underline{0.75}}$ & $\underline{\underline{0.63}}$ & $\underline{\underline{0.49}}$ & $\underline{\underline{0.34}}$ & $\underline{\underline{0.18}}$ \\
\hline
\end{tabular}

Note: the bank immediately recognizes the gains on securitization and changes in fair value of retained interest into earnings.

Figure 5. With securitization when IRR is $10 \%$.

considerable body of studies suggesting that fair value is an uncertain estimate when valuing equity price, Barth and Landsman [3] and Blankespoor et al.[9] aruge that fair value is relevant to decision making and investors would be better informed by incorporating fair value into their security analysis. Not only realized fair value 
gains or losses but alos unrealized component can have predictive power on future earnings where Jones and Smith [10] show that unrealized fair value gains or lesses reported in other comprehensive income statement are relevant in equity pricing. Georgescu and Laux [11] studies three prominent German banks namely Deutsche Industriebank, Landesbank Sachsen Girozentrale and HypoReal Estate Holding during the period from 2007 to 2008 and suggest that the recognition of banks' assets at fair value played an important role in the demise of banks, these banks have failed in the GFC but they did not apply fair value in measuring bank assets. Schaffer [12] also argues that U.S. banks did not use fair value to write down and fire sell bank assets during the GFC. On the contrary, Laux and Leuz [13] show evidence of delayed write-downs by banks. Accounting information plays an important role in healthy functioning of financial systems, nonetheless accounting standards have not kept pace with financial market developments, changes in the market landscape and financial innovation which is evident from the above analysis of assets securitization transactions and its association with fair value.

\section{Fair Value and Derivative Hedging}

Derivative hedging remains a major topic of controversy in accounting standards. One aspect of IAS 39 is the recognition of derivatives transactions on the balance sheet, which was suggested to be a significant improvement over the historical cost accounting where derivative transactions are recorded only off-balance sheet. Companies use derivative contracts mainly to hedge or offset business risks.

For example, on 1 July 2, 2012 a UK manufacturer committed to buy \$500 m of materials from a US supplier on 31 December 2012 and on this particular date the amount of $\$ 500 \mathrm{~m}$ needs to be delivered. Assume the spot rate on 1 July 2, 2012 is $\$ 1=£ 0.54$ and in the future the US dollar might rise against the British pounds and thus increase the dollar cost of the materials. To hedge this exchange rate risk, the UK manufacturer immediately bought a forward contract from Barclays Bank requires $\$ 500 \mathrm{~m}$ to be delivered to itself on 31 December 2012 at a price of $\$ 1=£ 0.54$. On 31 December 2012, if the US dollar is stable at $\$ 1=£ 0.54$, the UK manufacturer can buy $\$ 500$ from Barclays at the price of $£ 270 \mathrm{~m}$ and then use $\$ 500$ to pay the materials, no gain and loss in this case. If the US dollar falls, assuming $\$ 1=£ 0.50$, the manufacturer will suffer a loss on the forward contract because the contract obliges the manufacturer to buy the dollar at the price $£ 270 \mathrm{~m}$, but gain on the materials cost saving which now it costs $£ 250 \mathrm{~m}$. If the US dollar rises to $\$ 1=£ 0.60$, the manufacturer will enjoy a profit on the forward contract because the contract obliges the bank to sell the dollar at the price $£ 270 \mathrm{~m}$, but loss will occur from increased materials cost of $£ 300 \mathrm{~m}$.

Under IAS39, if the dollar falls against the pound, the derivative forward contract becomes a liability and a loss is immediately recorded because the derivative is marked to market. Ironically, the savings in the materials cost from change in the fair value of hedged item is not accounted for. As a result, the UK manufacturer's attempt to protect itself from changes in the dollar leads to a loss when the dollar falls. Likewise, when the dollar rises against the pound, the derivative forward contract is recorded on the balance sheet as an asset and the gain from change in the fair value is immediately recognized in earnings. But the higher material cost from change in the fair value of hedged item again is not recorded. So, the reported earnings become artificially high.

IAS39 then revised to allow for hedge accounting where both the hedged items and hedging instruments are fair valued and changes of hedged items and hedging instruments are in opposite directions, which would be automatically offset and only the net change would be taken to profit and loss account. In other words, the gain/loss of the hedged items and the gain/loss of the hedge instrument under the hedging accounting are recorded in earnings at the same time in attempt to eliminate undesired volatility in a firm's reported earnings stream (see Figure 6 \& Figure 7).

To be qualified for this accounting treatment, IAS 39 requires that a hedge must be "highly effective" in offsetting the risk. A hedge is regarded as highly effective if the following two criteria are met: 1) the hedge is expected to be highly effective in offsetting changes in fair value of cash flows attributable to the hedged risk; 2) the actual results of the hedge are within a range of $80 \%-125 \%$. Though, the term "highly effective" is a subjective measurement. The first criteria implies a perfect negative correlation between changes in the value of hedging instrument and changes in the value of hedged item, which is unlikely in many circumstances. So, the second criterion relaxes the condition to a range of acceptable value changes for the derivative. For example, if Figure 7 the gain on the hedging instrument is $£ 30 \mathrm{~m}$ and the loss on the hedged item which is the material cost is $£ 24 \mathrm{~m}$, offset in the profit and loss account can be measured by 30/24, which is $125 \%$. Since the gain on forward contract falls within the up bound, the forward contract has been an effective hedge. Despite the transaction 


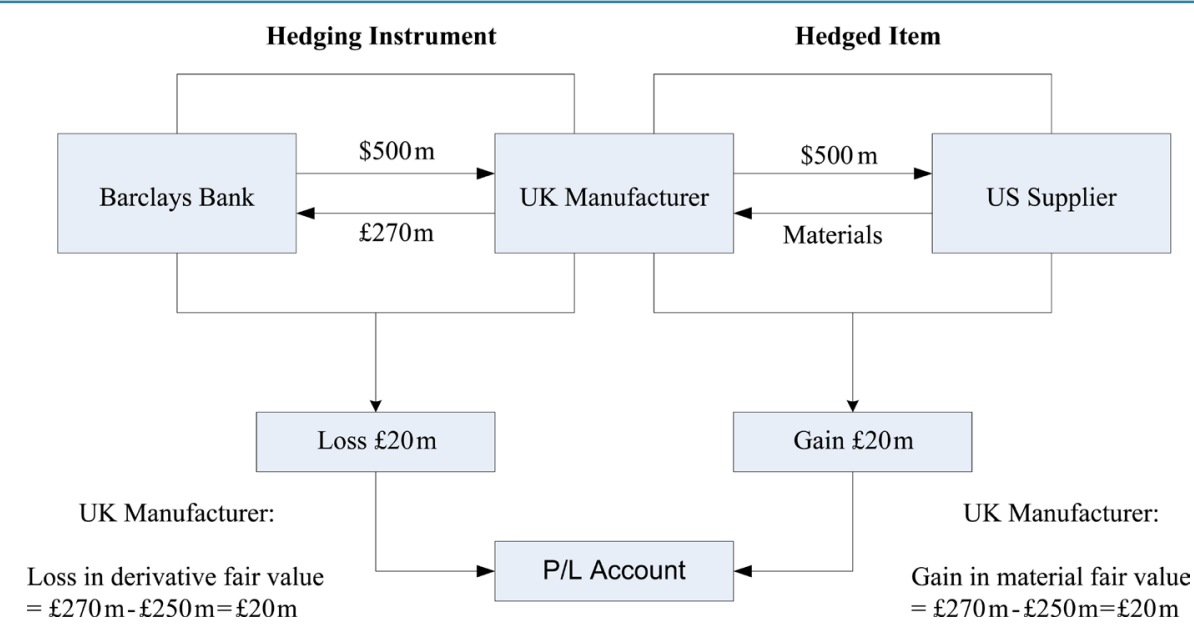

Figure 6. Fair value and hedging effect when USD dollar falls.

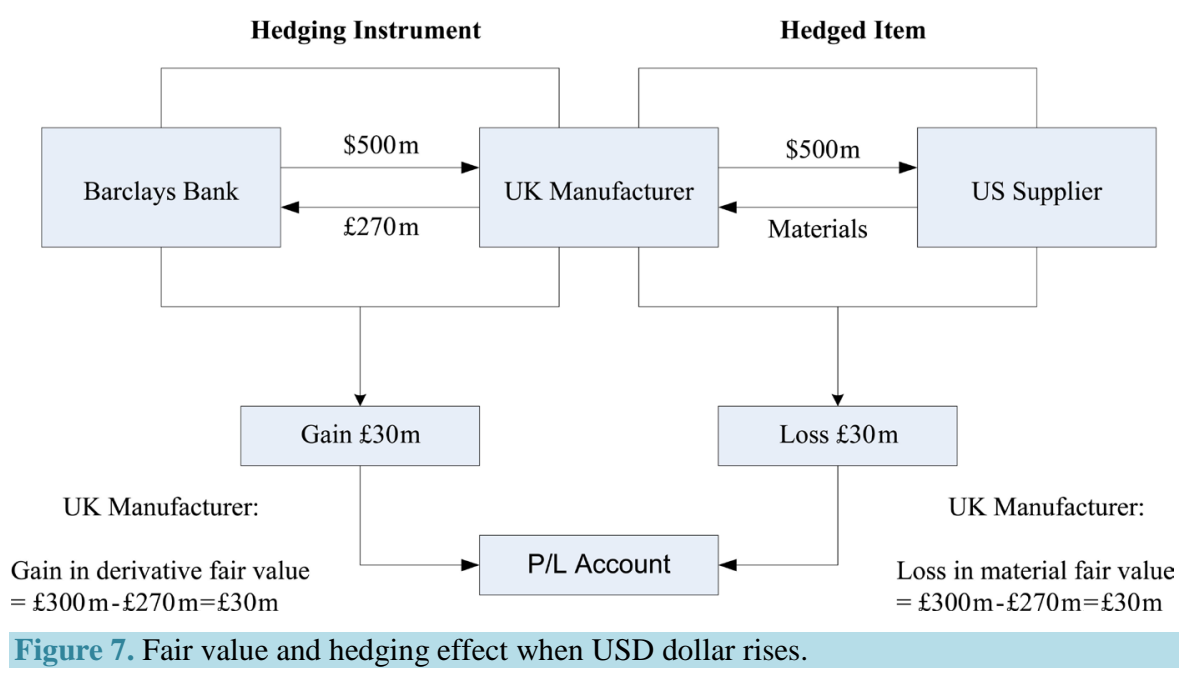

under the second criterion is qualified as a highly effective hedge, there is an excess gain $£ 6 \mathrm{~m}$ would be recognized in current income statement which has a direct impact on reported earnings. Moreover, if these two criteria are not satisfied, a hedge will be terminated and deferred gains or losses on the derivative are recognized in current earnings. This not only reintroduces volatility into a company's reported earnings but also increases the company's financial risk as leverage increases. Therefore, whether a fair value hedge, a mark-to-market derivative volatility will be offset by a mark-to-market asset or liability volatility, will also mitigate earnings volatility that caused by changes in foreign currency rates remains an open question.

IAS 39 permits two types of hedge accounting, fair value hedge accounting that discussed in the above example and cash flow hedge accounting. Cash flow hedge accounting relates to the hedging of future cash flows, for example, selling a credit default swap to protect the future loan repayments, so the future cash flows which are the loan repayments have not yet occurred and thus will not be recorded in the accounts. This is different from fair value hedging where certain derivative contract is used to offset the effects of a particular risk factor such as exchange rate risk on the value of a hedged item that has already occurred and held in the accounts. The accounting treatment is also different between fair value hedging and cash flow hedging. In fair value hedging as shown in Figure $6 \&$ Figure 7, both the hedging instrument and the hedged item are measured at fair value and changes in the fair value will be adjusted in profit and loss account. Under the cash flow hedging, however, the changes in the fair value of the hedging instrument will be excluded from the profit and loss account and recorded direct in equity account. Until the time when the hedge item, the future cash flow is realised, the changes in the fair value of the hedging instrument then will be recycled to the profit and loss account. Hedging accounting is especially concerned by some banks because the treatment not only create volatility in earnings, but 
also lead to volatility in equity, gains and losses on hedging instruments being held there before recycling. Essentially, fair value hedging advances the income statement recognition of gains/losses whereas cash flow hedging delays the income statement recognition of gains/losses, both have the potential to create volatility in the financial statements, which in turn may impact on financial performance of a company.

\section{Fair Value and Loan Loss Provision}

Loans comprise a significant proportion of bank assets and loan loss provisioning is also central in the debate. Originated loans according to IAS39 are held at historical cost and adjusted for amortization and are subject to impairment testing. A loan is impaired if it is probably that a bank will be unable to collect all amounts due. Banks recognized loan losses under an incurred loss model and this model does not recognize a provision for a loan loss until there is objective evidence the loan has been impaired. The concept of "incurred loss" essentially delays loss recognition as this view suggests that a financial statement should reflect events that have occurred within the reporting period and should not reflect events that have not yet occurred. As a result many banks did not recognize losses even when the housing bubble went bursting and a substantial number of borrowers showing a sign of default in paying down their loans. Moreover, this model provides an asymmetric recognition that loans are only written down in the economic downturns but not up when the economic is the booming.

The incurred loss model is less procyclical because it delays loss recognition in the value of loans, but such delayed recognition of loan losses is criticized to facilitate the exertion of pressure by stakeholders and regulators to take corrective action. The timelier detection of any asset losses, the sooner the stakeholders and regulators can become fully aware of the problem and take the necessary actions. Accounting in provision should adopt a pro-active approach that tries to identify expected losses as soon as possible and this particularly important to financial institutions. If, during economic boom, the accounting system is not sufficiently flexible to allow the recognition of possible future loan losses, the impact will be much greater in the economic recession, because huge amounts of losses will suddenly have to be recognized. So, the incurred loss model was criticized to deepen the crises. IASB has been questioned in this regard, they later proposed an expected loss model that explicitly incorporates a forward looking approach to identify expected losses as soon as possible that is comparable to sound risk management.

In January 2011, the expected loss model was proposed with a forward looking approach in recognizing loan losses. Under this model, a bank would reflect all changes either increases or decreases in expected future cash collections from its loans in the loan loss provisions. This model allows timely and symmetric loss recognition by banks but the problem is it does not change the discount rate in calculating the present value of the expected future cash flows when market interest rates change. Therefore, the value of expected future cash flow collections under the expected loss model is not fully reflected. If a bank uses the fair value model to recognize loan loss provisions, it would be more effective compared to the incurred and the expected loss models because the bank can recognize in its loan loss provisions not only changes in expected future cash flow collections but also changes in the discount rate that arise from changes in market interest rates.

Although measuring loans at fair value tends to provide information about loan values that is most relevant to the market, it could have amplified procyclicality effect during the Crisis. When property prices fall sharply during 2009, many banks were not able to recover the home loans and the losses from declining fair value in home loans had to be written off against capital. The amendment of IAS39 permits non-derivative financial assets held for trading and available for sale financial assets to be reclassified in certain situations. The purpose was to enable banks to record financial assets which are no longer traded in an active market at amorised cost, thereby reducing reported profit or loss volatility. The reclassification is substantially determined by the management intention if financial assets are no longer held for the purpose of trading-being sold or repurchased in the near term. For example, reclassify trading Financial assets or financial liabilities to loans and receivable if the assets meet the loans and receivables definition, if the entity has the intention and the ability to hold them for the foreseeable future; financial assets that are not eligible for loans and receivables, may be transferred from trading to available for sale or held to maturity, only in "rare" circumstances; financial assets may only be transferred into the held to maturity category if the entity has the positive intent and ability to hold them to maturity. CESR [14] surveyed 100 EU financial companies and found that about half had reclassified their financial assets to avoid further losses.

While fair value-related impairment charge could have amplified procyclicality of bank asset prices in theory, 
it was not supported empirically. Laux and Leuz [13] report that fair value was not used in a large magnitude by banks in measuring loans and leases during the period of 2004 to 2006. Shaffer [12] studies 14 largest US commercial banks during the GFC and found that the decline in Tier 1 capital arising from impairments to fair value of available-for-sale and held-to-maturity assets averaged only $2.1 \%$, arising from impairments of loans averaged $15.6 \%$ but those impairments were based on an incurred loss model. These empirical evidences suggest that fair value should not be accursed to result in a greater procyclicality simply because loans were not measured at fair value for financial reporting purposes. The notion of dynamic provisioning advocated by the Bank of Spain seems to mitigate procyclicality. The dynamic provisioning approach proposes a creation of capital reserves for banks during good economic times to use to absorb capital declines in economic downturns. Technically, banks need to increase loan loss provisions in economic upturns while decrease them in economic downturns in order to create a countercyclical tool. This approach can be viewed as a specific extension of forward-looking provision in the senses that it intends to reflect credit risk over the whole life of the loan, thus cushioning the impact from loan impairment losses that are recognized in a single accounting period.

\section{Conclusion}

This study analyzes and shows the way in which financial reporting for fair values, assets securitization, derivative hedging and loan loss provisioning potentially introduced volatility into the financial system. These are a number of issues which are particularly important for financial stability that were evidenced in the GFC. For each topic, this study analyzes how the fair value measurement could lead to greater volatility in reported earnings, the reasons why the volatility might be artificial and even if the volatility were "real" to what extent it could be a source of procyclicality. On one hand, financial accounts that measured by fair value tend to have incremental power in explaining stock price movements. For average investors, they require a genuine understanding of a firm's business model and the economic risks and potential rewards that the firm faces, and the value relevance findings suggest that fair value provides useful information in supporting investment decision making. On the other hand, market valuation of firms is largely driven by earnings expectation and volatility in earnings is likely to increase the firm's cost of capital because risk natural investors tend to demand a higher risk premium for an investment in the firm with greater earnings volatility. The concept of fair value is a key element in the international accounting standards and its implementation poses serious concerns in terms of financial stability. Fair value measurement is supported on the ground that it provides information which is more relevant to the economic substance and presumably such information will be more useful to investors. However, the other objectives of financial reporting, namely reliability and comparability, are achievable only if the measures of fair value are clear and reliable. In the absence of an active market, fair value must be estimated and this could accompany estimation errors or subject to management discretions. As a consequence, fair value has the potential to introduce volatility into the financial system. Besides the measurement, volatility could also be introduced into the financial system via inadequate accounting recognition and disclosure of fair value.

\section{References}

[1] IASB (2015) IFRSs. International Accounting Standards Board. http://www.iasb.org/IFRSs/IFRS.htm

[2] BIS (2009) BASEL II. Bank for International Settlements. www.bis.org/publ/bcbsca.htm

[3] Barth, M.E. and Landsman, W.R. (2010) How Did Financial Reporting Contribute to the Financial Crisis? European Accounting Review, 19, 399-423. http://dx.doi.org/10.1080/09638180.2010.498619

[4] Hull, J. (2008) The Financial Crisis of 2007: Another Cased of Irrational Exuberance, The Financial Crisis and Rescue, Rotman School of Management. University of Toronto Press, Toronto, 17-31.

[5] Ryan, S.G. (2008) Accounting in and for the Subprime Crisis. The Accounting Review, 83, 1605-1638. http://dx.doi.org/10.2308/accr.2008.83.6.1605

[6] Schipper, K. and Yohn, T.L. (2007) Standard-Setting Issues and Academic Research Related to the Accounting for Financial Asset Transfers. Accounting Horizons, 21, 59-80. http://dx.doi.org/10.2308/acch.2007.21.1.59

[7] American Accounting Association's Financial Accounting Standards Committee (AAA) (1996) Response to the FASB Exposure Draft, "Proposed Statement of Financial Accounting Standards-Accounting for Transfers and Servicing of Financial Assets and Extinguishment of Liabilities”. Accounting Horizons, 10, 178-181.

[8] Niu, F.F. and Richardson, G.D. (2006) Earnings Quality, Off-Balance Sheet Risk, and the Financial-Components Approach to Accounting for Transfers of Financial Assets. Working Paper, Wilfrid Laurier University and University of 
Toronto.

[9] Blankespoor, E., Linsmeier, T.J., Petroni, K. and Shakespeare, C. (2013) Fair Value Accounting for Financial Instruments: Does It Improve the Association between Bank Leverage and Credit Risk? Accounting Review, 88, $1143-1177$. http://dx.doi.org/10.2308/accr-50419

[10] Jones, D.A. and Smith, K.J. (2011) Comparing the Value Relevance, Predictive Value, and Persistence of Other Comprehensive Income and Special Items. The Accounting Review, 86, 2047-2073. http://dx.doi.org/10.2308/accr-10133

[11] Georgescu, O. and Laux, C. (2013) Financial Reporting, Financial Regulation, and Financial Stability Evidence from German Bank Failures in 2007-2008. Working Paper, Goethe University and Vienna University.

[12] Schaffer, S. (2010) Fair Value Accounting: Villain or Innocent Victim-Exploring the Links between Fair Value Accounting, Bank Regulatory Capital and the Recent Financial Crisis. Working Paper, Federal Reserve Bank of Boston Quantitative Analysis Unit.

[13] Laux, C. and Leuz, C. (2010) Did Fair Value Contribute to the Financial Crisis. Journal of Economic Perspectives, 24, 93-118. http://dx.doi.org/10.1257/jep.24.1.93 https://www.aeaweb.org/articles.php?doi=10.1257/jep.24.1.93

[14] CESR (2009) CESR Statement on the Reclassification of Financial Instruments and Other Related Issues. CESR, 08-937. 